\title{
Deslocamentos, itinerários e destinos de populações atingidas por Barragens: UHE Tijuco Alto, SP - $\mathrm{PR}^{*}$
}

\section{Displacements, Itineraries and Destinations of Populations Affected by Dams: HP Tijuco Alto, SP - PR}

\author{
Alexandre Cosme José JERONYMO** \\ Célio BERMANN*** \\ Sinclair Mallet Guy-GUERRA****
}

\begin{abstract}
RESUMO
As Usinas Hidrelétricas de Energia (UHE) produzem impactos sociais, econômicos e ambientais de difícil quantificação. Dentre os impactos provocados está a apropriação de propriedades para compor a área de influência direta da UHE. A partir do processo de apropriação, iniciam-se os deslocamentos involuntários de famílias e comunidades rurais inteiras. $\mathrm{O}$ deslocamento familiar decorrente de projeto hidrelétrico não construído e as condições materiais de existência após o deslocamento são impactos sociais pouco analisados pela literatura. Este tipo de análise reduz quando ocorre a apropriação de propriedades para compor projeto de UHE não construída. Esta pesquisa analisa os deslocamentos familiares para a construção do projeto UHE Tijuco Alto (entre os Estados de São Paulo e Paraná, no rio Ribeira de Iguape), bem como os seus reflexos para a dinâmica econômica das comunidades inseridas na área de influência direta. O projeto hidrelétrico foi apresentado em 1989 e, desde então, foi iniciado o processo de apropriação de propriedades, seguido de deslocamentos familiares e esvaziamento das comunidades rurais. Entretanto, a construção da usina não foi materializada porque os estudos de impactos ambientais não foram protocolados no órgão ambiental correto e apresentavam insuficiências. Para o desenvolvimento da pesquisa, foram consultadas 29 famílias (que negociaram propriedade de terras) e outras 17 famílias (que trabalhavam em propriedades negociadas). A conclusão do trabalho aponta que o deslocamento produziu rupturas sociais, crise na economia comunitária e deslocamentos (municipais, intermunicipais e interestaduais). Além disso, aponta que os deslocamentos significam inserções social e profissional precárias, contraposto ao aumento no consumo de equipamentos eletrodomésticos, eletroeletrônicos e material para infraestrutura residencial.
\end{abstract}

Palavras-chave: usina hidrelétrica; população ribeirinha; deslocamentos.

\footnotetext{
"Este artigo baseia-se em parte da dissertação de mestrado do primeiro autor.

"* Doutor em Energia (UFABC). Instituto Brasileiro de Estudos Contemporâneos (IBEC). E-mail: alexandrecjj@yahoo.com.br

*** Doutor em Planejamento de Sistemas Energéticos (UNICAMP). Professor Associado (Livre Docente) no Instituto de Eletrotécnica e Energia da Universidade de São Paulo (USP). E-mail: cbermann@iee.usp.br

${ }^{* * * * *}$ Livre Docência pelo Departamento de Energia da Faculdade de Engenharia Mecânica da UNICAMP. Professor Titular na Universidade Federal do ABC (UFABC). E-mail: sguerra@ufabc.edu.br
} 


\begin{abstract}
The Hydroelectric Power Plants (HP) produce social, economic and environmental impacts which are difficult to quantify. Among these impacts is the appropriation of property that will comprise the area of direct influence of the HP. The involuntary displacement of families and entire rural communities begins with the appropriation process. The family displacement caused by the unbuilt hydroelectric project and the material conditions of existence after the displacement are some of the social impacts rarely analyzed in the literature. This type of analysis is reduced when the appropriation of properties to form unbuilt HP project occurs. Little is known about the appropriation of property for unbuilt hydropower projects and, therefore, it requires scientific contribution. This research analyzes the family displacement due to the construction of the HP Tijuco Alto (between the States of São Paulo and Paraná, in the river Ribeira do Iguape) -, and its consequences for the economic dynamics of rural communities from the area of direct influence. The HP project was presented in 1989 and it has since then started the process of appropriation of property followed by family displacement and emptying of rural communities. However, the HP construction has not materialized because the environmental impact studies were not registered at the proper environmental organization and it also presented deficiencies. For the development of the research 29 families (who negotiated land ownership) and other 17 families (who worked on traded properties) were consulted. The conclusion of the research points out that the displacement generates social disruption, economic crisis in the community and displacement (municipal, intercity and interstate). Furthermore, it shows that displacement means precarious social and professional inclusion, in contrast to the increase in consumption of electrical appliances, electronics and materials for residential infrastructure.
\end{abstract}

Keywords: hydroelectric; riverine population; displacement.

\section{Introdução}

As Usinas Hidrelétricas de Energia (UHE) geram energia elétrica para o consumo industrial, comercial e serviços. Embora elas tenham importância fundamental, as suas construções produzem múltiplos e variados impactos. Os trabalhos da Comissão Mundial de Barragens - CMB (2000), Conselho de Defesa dos Direitos da Pessoa Humana - CDDPH $^{1}$ (BRASIL, 2010), Zhouri, Laschefski e Paiva (2005), Bermann (2001), Sigaud (1988) e Vainer (1996) apontam que os reservatórios das UHE deixam submersos patrimônios naturais e os espaços de reprodução sociocultural das comunidades ribeirinhas, afetam laços de sociabilidade, provocam degradações ambientais, induzem a proliferação de insetos transmissores de doenças, os rios têm os seus leitos modificados e isto influencia na qualidade da água e na presença de peixes. Tais impactos são provenientes de projetos hidrelétricos construídos ou em construção.

Este trabalho trata de projeto hidrelétrico não construído; todavia, se faz presente no quotidiano o regional: o projeto UHE Tijuco Alto, no rio Ribeira de Iguape, entre os Estados de São Paulo e Paraná. O projeto foi apresentado à sociedade do Vale do Ribeira e protocolado nos órgãos de licenciamento ambiental dos estados paulista e paranaense em 1989. O primeiro projeto foi indeferido. O segundo projeto foi apresentado e recebeu novo indeferimento. $\mathrm{O}$ terceiro projeto foi apresentado em 2005 e encontra-se sob a análise do Instituto Brasileiro de Meio ambiente e Recursos Renováveis - IBAMA.

Independente da inexistência física da obra, já existe impacto regional provocado pela apropriação de propriedades e o consequente deslocamento social involuntário. Foram pesquisados os deslocamentos, os itinerários e os destinos das famílias deslocadas, as condições de subsistência em períodos anterior e posterior ao deslocamento para 29 famílias proprietárias e 17 não proprietárias e os reflexos para a economia das comunidades rurais após o deslocamento.

A introdução e outras seis seções integram o trabalho. A primeira seção demonstra as disputas existentes entre o uso comunitário e o uso social do recurso, a manutenção da subsistência contraposta ao uso privado para geração

\footnotetext{
${ }^{1}$ O Conselho de Defesa dos Direitos da Pessoa Humana (CDDPH) foi criado pela lei n 4.319, de 16 de março de 1964. O Conselho tem importância na promoção e na defesa dos direitos humanos no país.
} 
hidrelétrica. A segunda apresenta a produção industrial eletrointensiva e a Companhia Brasileira de Alumínio propondo, atuando e apropriando propriedades para compor o projeto UHE Tijuco Alto. A terceira apresenta os mecanismos utilizados para o desenvolvimento da pesquisa. O processo de apropriação de propriedades e o fluxo dos deslocamentos involuntários estão na quarta seção. A quinta seção destaca a crise econômica das comunidades ribeirinhas após os deslocamentos e as condições materiais e de subsistência das famílias deslocadas. Finalmente, a sexta seção apresenta as conclusões.

\section{Revisão da literatura}

$\mathrm{Na}$ matriz de energia elétrica brasileira predomina a geração a partir das Usinas Hidrelétricas (UHE). Isto acontece porque muitos rios do país apresentam condições hidrológicas favoráveis para a construção destes empreendimentos. Porém, os custos que envolvem as construções hidrelétricas são elevados e a sua remuneração nem sempre responde pelos interesses do investidor. Entretanto, tais obras são identificadas como viáveis, uma vez que os rios apresentam potencial para construções de UHE. Em regra geral, os custos dos investimentos são muito elevados (devido aos trabalhos de engenharia civil) e os custos de exploração são muito baixos (MARTIN, 1992, p. 36). Mesmo com os custos elevados, a Comissão Mundial de Barragens - CMB (2000) identificou 45.000 barragens no mundo e a Agência Nacional de Energia Elétrica (ANEEL, 2011) informa a existência de 2.416 empreendimentos hidrelétricos produzindo 118.458 .856 kilowatt (kW), dos quais $83.196 .942 \mathrm{~kW}$ são provenientes de UHE e Pequenas Centrais Hidrelétricas e os restantes estão entre as termelétricas, fotovoltaica, eólicas e nucleares.

As lógicas para a apropriação e para o uso do recurso natural são distintas e produzem conflitos. A lógica privada apropria propriedades e recursos naturais e os utilizam como mercadorias para geração hidrelétrica. A lógica social, por sua vez, faz uso da propriedade e dos recursos para reprodução comunitária, subsistência cultural e como meio de vida. São regimes distintos de propriedade, em aberto conflito um contra o outro.

Dentre os mecanismos utilizados pela lógica privada, segundo Castro e Andrade (1988, p. 10), estão a assimilação das populações humanas a uma natureza e a anulação das suas histórias e conhecimentos, por um lado, e a obra é apresentada como sujeito do processo e responsável pelas transformações sociais e econômicas regionais, por outro lado. Além disso, na análise de Germani (2003, p. 62), o capital vai definindo a utilização-reprodução espacial e subordinando a economia dos produtores da região. As terras e os seus recursos, neste sentido, integram a lógica do mercado, do lucro e da maior produtividade As comunidades rurais, as famílias e o meio ambiente inseridos no espaço identificado como apto para construção do empreendimento são removidos. O espaço social-comunitário é modificado pela presença e pela ação do agente econômico. O empreendimento é agora o sujeito do processo e o espaço social-comunitário é o espaço da obra. Segundo Vainer:

Esta naturalização da população produz, nos estudos e previsões, um pastiche em que o social está destituído de todos os atributos, características e qualidades que fazem dele algo essencialmente em ruptura com o físico biótico. O principal atributo recusado a este social naturalizado e ecologizado é o atributo da historicidade (VAINER, 1996, p. 190).

Na análise de Zhouri, Laschefski e Paiva:

A predominância de uma concepção reducionista e hegemônica que define os modos de uso e dos recursos naturais que seguem uma lógica meramente mercantil impede que as comunidades atingidas por barragens sejam reconhecidas como sujeitos ativos e constitutivos do espaço de discussão e de deliberação (ZHOURI; LASCHESFKI; PAIVA, 2005, p. 98-99).

Os percursos dos agentes econômicos para apropriar propriedades de terras e instalar empreendimentos hidrelétricos utilizam o discurso do desenvolvimento regional, projetos de regularização e contenção de cheias, melhorias na infraestrutura para abastecimento de águas, irrigação e piscicultura e geração de empregos. Os empreendimentos hidrelétricos são voltados para o desenvolvimento de áreas territoriais, ainda não economicamente integradas à economia de mercado (WALDMANN, 1990, p. 42) e, supostamente, necessitando de incentivos para inclusão. Para Vainer e Araújo (1992, p. 71), os empreendimentos identificam regiões inteiras, extensíssimas bacias e ricas várzeas em jazidas energéticas. Entretanto, a lógica privada é implantada quando o espaço cobiçado apresenta potencial para exploração dos recursos e a reprodução do capital. 
A literatura que estuda os impactos provocados pelas construções de UHE é ampla. A invisibilização (LEROY, 2001), a assimilação e a naturalização das famílias e comunidades ribeirinhas ao ambiente natural (CASTRO; ANDRADE, 1988, p. 13; VAINER, 1996), as inundações dos patrimônios naturais provocadas pelos enchimentos dos reservatórios hidrelétricos (BERMANN, 2001; CMB, 2000; ZHOURI; LASCHEFSKI, PAIVA, 2005), os deslocamentos humanos (GERMANI, 2003) e a dificuldade para as famílias deslocadas receberem as compensações e indenizações obrigatórias (CMB, 2000) contribuem para identificar e dimensionar os impactos causados pelas construções de UHE.

São diversas as interrogações que envolvem projetos hidrelétricos. A participação dos interessados no processo de tomada de decisão sobre a instalação, ou não, da UHE não prima pela transparência. O relatório da CMB (2000) reconhece nas construções de UHE um instrumento para o desenvolvimento, porém os seus processos decisórios não são transparentes e os impactos socioambientais provocados apresentam difícil mitigação e avaliação limitada. São avaliados com alcance limitado. O CDDPH (BRASIL, 2010), que recebeu denúncias de violação dos direitos humanos em $74^{2}$ UHE (em fase de licenciamento, implantação e operação) nas cinco regiões do país, acolheu e selecionou casos para investigação. O relatório da $\mathrm{CDPPH}$ confirma as denúncias apresentadas.

Os estudos de caso permitiram concluir que o padrão vigente de implantação de barragens tem propiciado, de maneira recorrente, graves violações de direitos humanos, cujas consequências acabam por acentuar as já graves desigualdades sociais, traduzindo-se em situações de miséria e desestruturação social, familiar e individual (BRASIL, 2010: p. 13).

E 16 (dezesseis) violações dos direitos humanos.

1) Direito à informação e à participação; 2) Direito à liberdade de reunião, associação e expressão; 3 ) Direito ao trabalho e a um padrão digno de vida; 4) Direito à moradia adequada; 5) Direito à educação; 6) Direito a um ambiente saudável e à saúde; 7) Direito à melhoria contínua das condições de vida; 8) Direito à plena reparação das perdas; 9) Direito à justa negociação, conforme critérios transparentes e coletivamente acordados; 10) Direito de ir e vir; 11) Direito às práticas e aos modos de vida tradicionais, assim como ao acesso e preservação de bens culturais, materiais e imateriais; 12) Direito dos povos indígenas, quilombolas e tradicionais; 13) Direito de grupos vulneráveis à proteção especial; 14) Direito de acesso à justiça e à razoável duração do processo judicial; 15) Direito à reparação por perdas passadas; 16) Direito de proteção à família e aos laços de solidariedade social ou comunitária (BRASIL, 2010, p. 15).

A conclusão do CDPPH confirma as denúncias e pesquisas desenvolvidas anteriormente. O processo de destituição do outro, das suas histórias e conhecimentos está associada ao invisibilizar. A observação de Leroy (2001, p. 9) reconhece que as populações ribeirinhas são invisibilizadas pelos governos, pelos bancos multilaterais, pelas empresas construtoras e pelos consultores que elaboram Estudos de Impacto Ambiental (EIA). Uma vez que esta população é invisibilizada, a sua participação no processo de tomada de decisão é anulada. Fazer uso do recurso da invisibilidade é recorrer às vias que se seguem.

VIA 1 - Promover a invisibilidade das informações ao construir assimetria, visando dificultar ações e organizações políticas dos grupos sociais presentes na região apropriada para o empreendimento, ou seja, diminuir o campo das disputas e utilizar a política do fato consumado, que é a inexorabilidade do desenvolvimento regional via construção da UHE. O campo da política, hipoteticamente o campo do possível, fica anulado. Para Rancière:

Hoje, alguns grupos e instituições defendem a ideia de que estamos sujeitos à lei do inevitável [...] Ora, a política deve ser o campo do possível, não o campo do inevitável. É importante que possa haver escolha (RANCIÈRE, 1996).

VIA 2 - A invisibilidade como recurso econômico. A invisibilidade pode reduzir custos com investimentos através da presença de EIA deficientes, pouco precisos, invisibilizando comunidades atingidas e a existência de infraestrutura (estradas, casas, pontes), bem como de cultivos e animais. Incluir a infraestrutura, cultivos e animais no EIA pode representar custos elevados e redução das taxas de retorno dos investimentos.

\footnotetext{
${ }^{2}$ Foram escolhidas para o desenvolvimento da pesquisa a UHE Aimorés, a UHE Cana Brava, a UHE Chapecó, a UHE Tucuruí, a Pequena Central Hidrelétrica (PCH) Emboque, a PCH Fumaça e o açude para abastecimento de água Acauã (BRASIL, 2010, p. 5).
} 
A função do ferramental invisibilidade reduz os custos do investimento e o não reconhecimento dos grupos sociais constituídos historicamente e, da mesma forma, diminui o campo da política como o campo das negociações e possibilidades.

A contraposição da prática da invisibilidade tem sido desenvolvida com a presença das populações envolvidas. O posicionamento dos movimentos sociais (Movimento dos Atingidos por Barragens - MAB) e o das Organizações Não Governamentais (ambientalistas) contribui para visibilizar as famílias e regiões que possam ser atingidas pela construção de UHE. A existência do Conselho de Defesa dos Direitos da Pessoa Humana e a audiência pública (instrumento legal obrigatório para informar e debater projetos de UHE) são tributários da visibilização da diversidade dos impactos sociais, culturais, econômicos e ambientais proporcionados pelas construções de UHE. As audiências públicas, em específico, são esferas públicas para ampliar os canais de informações sobre o projeto proposto, o licenciamento ambiental como instrumento de gestão ambiental, bem como são a oportunidade para fornecer atenção às demandas sociais da comunidade.

O posicionamento dos movimentos sociais e o das ONGs reflete a organização social e representa a integração social junto às esferas públicas. Entretanto, conforme Jacobi (2005, p. 134), o grande desafio é que esses espaços sejam efetivamente públicos, tanto no seu formato quanto no resultado. Segundo Souza e Jacobi (2011, p. 254), de um lado temos uma sociedade civil cada vez mais atuante $\mathrm{e}$ participativa dos espaços de construção e gestão de políticas públicas de caráter deliberativo e, de outro, um instrumento de gestão ambiental que ainda entende essa participação cidadã numa perspectiva consultiva. Isto significa dizer que a pressão exercida pelas demandas sociais e a ampliação das esferas públicas participativas, no caso dos instrumentos para gestão ambiental, requerem maturidade. A maturidade das deliberações da organização social e a pressão junto ao poder público pela resolução das demandas sociais são contrapostas ao caráter consultivo das esferas públicas. A ampliação das esferas públicas, portanto, não necessariamente significa maior participação nos processos decisórios sobre projetos para construção de empreendimentos hidrelétricos e, neste sentido, por si só, não podem representar a pluralidade de informações.

\section{Consumo industrial eletrointensivo}

As indústrias pesadas são as principais consumidoras de eletricidade e por isso são classificadas como eletrointensivas. Aí se encontram as indústrias de cimento, siderurgia (ferro-gusa e aço), alumínio, o setor químico e o de papel e celulose. Já as indústrias leves são as têxteis, de alimentos, bebidas e cerâmicas. O elevado consumo de eletricidade é objeto de preocupação desses ramos industriais e de apreciação pelo poder público.

No caso brasileiro, o grande consumidor de eletricidade tem a oportunidade para produzir a eletricidade necessária para a própria planta industrial. $\mathrm{O}$ decreto $\mathrm{n}^{\circ}$ 23/1996, da Agência Nacional de Energia Elétrica (BRASIL, 1996), regulamenta a produção de energia elétrica por produtor independente e autoprodutor, a partir da concessão ou autorização para produzir energia elétrica destinada ao seu uso exclusivo.

\section{Companhia Brasileira de Alumínio e o projeto UHE Tijuco Alto}

A particularidade eletrointensiva da atividade industrial da Companhia Brasileira de Alumínio - CBA - (produtos fundidos e transformados) a remete para a autoprodução de eletricidade e para o consumo eletrointensivo de energia elétrica. Para responder as demandas pelo consumo de energia elétrica da própria planta industrial, a CBA propõe a construção da UHE Tijuco, concebida para o trecho federal do rio Ribeira de Iguape, entre São Paulo e Paraná.

A CBA é responsável por 5 Pequenas Centrais Hidrelétricas (PCH) e 12 UHE, as quais, conjuntamente, produzem para a Companhia 1.057,85 MW. Algumas dessas são consorciadas e outras próprias.

\section{Projeto UHE de Tijuco Alto}

As cidades de Adrianópolis, Cerro Azul/PR, Dr. Ulysses/PR, Itapirapuã Paulista/SP e Ribeira/SP foram inclusas na Área de Influência Direta (AID) do projeto UHE Tijuco Alto. ${ }^{3}$ A organização social, cultural e econômica das comunidades rurais incluídas na AID, antes

${ }^{3}$ Assuntos detalhados na sequência desta. 
do processo de apropriação de propriedades, demonstra intensa relação comunitária. Segundo o EIA do projeto Tijuco Alto desenvolvido pelo Consórcio Intertechne, Engemin, $\operatorname{IPEC}^{4}$ (1991, p. 493), os bairros rurais da AID encontram-se centralizados por uma Igreja, uma escola e um armazém, que atendem as populações e que constituem ponto de reunião para a vizinhança dispersa. As famílias, segundo o Consórcio, encontram-se articuladas ao redor de um conjunto de relações de vizinhança que caracterizam os chamados bairros rurais e proporcionam para os seus habitantes a noção do pertencer. Neste contexto, o estudo Intertechne, Engemin, IPEC (1991, p. 493-494) destaca a presença do catolicismo e das suas festas religiosas fortalecendo os laços comunitários e o pertencimento ${ }^{5}$ e, além dos elementos religiosos, ocorrem torneios esportivos de futebol entre os bairros rurais, organização de quermesses, bingos e almoço comunitário.

O estudo da Intertechne, Engemin, IPEC (1991, p. 495) constatou existência de ações do poder público municipal (Ribeira, Adrianópolis e Cerro Azul) incentivando a produção artesanal doméstica (panelas de barro) e da Emater oferecendo cursos de artesanato de palha do milho (para confeccionar cestos, balaios, redes, chapéus, esteiras) em Adrianópolis. Também foram identificadas organizações sindicais rurais em Cerro Azul (700 associados), Apiaí (800 associados) e Adrianópolis. Além disso, a indústria de mineração de chumbo Plumbum S.A. ${ }^{6}$, instalada em Adrianópolis, respondia pela principal atividade industrial municipal até 1995.

De modo geral, segundo o estudo do Intertechne, Engemin, IPEC (1991), o conjunto desses elementos representa o patrimônio cultural próprio.

Essas mostram-se com mais clareza nas práticas artesanais, festas religiosas, formas de lazer e de produção, que expressam em última instância as formas de organização sociocultural da região e constituem, em sua expressão intangível, o patrimônio cultural da área (INTERTECHNE; ENGEMIN; IPEC, 1991, p. 493).
A organização social, cultural e econômica da região inclusa na AID do projeto UHE Tijuco Alto tem sido sistematicamente desconstruída. Materialmente, a UHE Tijuco Alto não foi construída, ou seja, é um projeto. Entretanto, está presente no Vale do Ribeira. O projeto Tijuco Alto produziu e tem produzido modificações regionais desde quando foi apresentado como proposta de desenvolvimento regional para a sociedade vale-ribeirense.

Em 1989, a CBA protocolou documentos na Secretaria de Meio Ambiente (SMA) do Estado de São Paulo e na Superintendência dos Recursos Hídricos e do Meio Ambiente (SUREHMA) do Estado do Paraná, pleiteando licenças ambientais para o projeto UHE Tijuco Alto. As licenças prévias foram concedidas em 14/06/1994 pelo Conselho Estadual de Meio Ambiente/Secretaria Estadual do Meio Ambiente de São Paulo e em 22/02/1995 pelo Instituto Ambiental do Paraná (IAP). O licenciamento foi indeferido por meio de ação civil pública, amparada por uma mobilização envolvendo parlamentares, entidades ambientalistas, lideranças de comunidades do Vale do Ribeira e advogados. O motivo do indeferimento foi porque o Ministério Público julgou que o licenciamento não poderia ser estadual. Considerando que o local para a construção hidrelétrica é o leito federal do rio Ribeira de Iguape, causando impactos interestaduais, a lei ${ }^{\circ} 237$, art. $4^{\circ}$ (BRASIL, 1997) determina que o licenciamento ambiental seja competência do órgão federal, no caso, o Instituto Brasileiro de Meio Ambiente e Recursos Renováveis (IBAMA).

A segunda tentativa de obtenção de licenças ambientais ocorreu em 1997. Neste ano, a CBA protocolou documentos no IBAMA com vistas a obter as licenças ambientais para construção do projeto UHE Tijuco Alto. Esta segunda tentativa foi indeferida em 2003, desta vez pelas insuficiências no Estudo de Impacto Ambiental (EIA).

Ao protocolar pedido de licença ambiental junto aos órgãos ambientais incorretos, o agente econômico responsável pelo projeto UHE Tijuco Alto utiliza a invisibilidade como ferramenta, ao desconhecer e negligenciar a legislação ambiental e os órgãos responsáveis pelo licenciamento de

\footnotetext{
${ }^{4} \mathrm{O}$ consórcio formado pelas empresas Intertechnem, Engemin, IPEC foi o responsável pela elaboração do primeiro Estudo de Impacto Ambiental do projeto UHE Tijuco Alto.

${ }^{5}$ Dentre as festas religiosas, segundo o EIA do projeto Tijuco Alto organizado pelo Consórcio Intertechne, Engemin, IPEC (1991, p. 493) estão: a Festa de São Gonçalo em Cerro Azul (no Bairro Lajeadinho); Festa de São Sebastião (no Bairro São Sebastião); Festa do Bom Jesus de Itapirapuã, em Ribeira (no Bairro Itapirapuã); a Mesada dos Anjos, realizada como pagamento de promessas em Cerro Azul, Ribeira e Adrianópolis; Festa do Divino, realizada em Cerro Azul e Ribeira; a cerimônia do Beijar a Bandeira, realizada em Cerro Azul (bairros Lajeado Grande, Ribeirão do Veado e Freguesia); e a Festa da padroeira Nossa Senhora da Guia, em Cerro Azul. ${ }^{6}$ A mineradora Plumbum foi instalada na cidade de Adrianópolis em 1937. Em 1955 a mineradora encerrou as atividades no município.
} 
projeto de UHE que impacta dois ou mais Estados. A invisibilidade é continuada com a apropriação de propriedades, que reflete nos deslocamentos involuntários dos proprietários e não proprietários de terras e na crise econômica das comunidades rurais envolvidas. $^{7}$

Para operar a visibilidade, com relação ao projeto UHE Tijuco Alto, estão: Movimento dos Ameaçados por Barragens $\left(\mathrm{MOAB}^{8}\right)$, ONGs (Instituto Socioambiental, SOS Mata Atlântica, Associação Serrana Ambientalista, Centro de Estudos de Defesa e Educação Ambiental (CEDEA) e Sindicatos (Sindicatos da Agricultura Familiar do Vale do Ribeira - SINTRAVALE). O direito ao uso do solo e dos recursos, a sustentabilidade a partir dos projetos de desenvolvimento endógenos (não contemplam UHE no Vale do Ribeira), o valor cultural do rio Ribeira de Iguape (único rio sem barragem do Estado de São Paulo) e o das suas populações ribeirinhas compõem o quadro para operar a visibilidade. Visibilizar as pessoas, comunidades e culturas do Vale do Ribeira tem sido determinante para a não construção do projeto UHE. Dentre os mecanismos para visibilização estão: a reprovação dos procedimentos utilizados pela CBA para apropriação de propriedades quando o projeto foi anunciado, reuniões sobre os potenciais impactos (sociais, econômicos e ambientais) do projeto, manifestos contra a UHE ao longo da bacia hidrográfica do rio Ribeira de Iguape e em frente ao prédio do IBAMA (Instituto Brasileiro de Meio Ambiente e Recursos Renováveis) na cidade de São Paulo/SP e em Curitiba/PR, e bloqueios rodoviários. ${ }^{9}$ Além disso, a Assembleia Legislativa do Estado de São Paulo aprovou a lei $n^{\circ} 394 / 2007$, que transforma o rio Ribeira de Iguape em patrimônio histórico, cultural e ambiental, porém o parecer $n^{\circ} 1.816$, de $27 / 07 / 2007$, do governo estadual, vetou o projeto de lei.

A terceira tentativa para licenciar foi iniciada em 2004, com a apresentação da terceira versão do projeto UHE Tijuco Alto. Desde então, a CBA modificou as ações para obter as licenças ambientais. Por exemplo, uma nova construtora foi contratada (Companhia Nacional de Engenheiros Consultores - CNEC) e as famílias não proprietárias identificadas na AID do novo projeto hidrelétrico passaram a compor o grupo das famílias a receberem indenização. O passivo social já existente, decorrente das apropriações de propriedades iniciais e os seus reflexos (deslocamentos de não proprietários de terras e crise na economia das comunidades rurais), não é solucionado. Segundo o Boletim Informativo do Empreendimento UHE Tijuco Alto (CNEC, 2007) foram identificadas "31" famílias não proprietárias deslocadas (pelo processo de apropriação de propriedades inicial) que farão parte do processo de seleção para o reassentamento. Esta tentativa de visibilizar as famílias sem propriedade de terras e deslocadas sem indenização não responde pelo passivo já produzido e vivenciado e, da mesma forma, é questionável a existência de apenas "31" famílias representando a totalidade de famílias não proprietárias deslocadas.

Os resultados das ações iniciais da CBA continuam invisibilizados e o posicionamento das organizações sociais contrárias à construção do projeto UHE Tijuco Alto permanece com a proposta de desenvolvimento regional para o Vale do Ribeira alheia aos projetos hidrelétricos. O atual EIA/RIMA define que o projeto será construído no trecho interestadual do rio Ribeira de Iguape, na bacia hidrográfica do rio Ribeira de Iguape, conforme o mapa 1.

As definições da Área de Influência Direta (AID) e a Área de Influência Indireta (AII) são apresentadas a seguir.

Área de Influência Direta são áreas sujeitas aos impactos diretos da implantação e operação do empreendimento. [...] Área de Influência Indireta é uma área real ou potencialmente ameaçada pelos impactos indiretos da implantação e operação do empreendimento, abrangendo o ecossistema (biótico e não biótico) e o sistema socioeconômico que podem ser impactados por alterações ocorridas na Área de Influência Direta (CBA; CNEC, 2005b, p. 34-35).

A seguir são apresentadas informações do atual projeto UHE Tijuco Alto.

[...] a $11 \mathrm{~km}$ acima das cidades de Ribeira/SP e Adrianópolis/PR, atingindo 113 famílias rurais e 576 famílias urbanas, barragem com 120 metros de altura e potência instalada entre $120 \mathrm{MW}$ e $150 \mathrm{MW}$, reservatório com

\footnotetext{
${ }^{7}$ Assuntos abordados nas próximas seções.

${ }^{8}$ Representados pelas comunidades remanescentes dos Quilombos do Vale do Ribeira. O MOAB foi criado em 1989 , a partir do anúncio da construção do projeto UHE Tijuco Alto.

${ }^{9}$ A Rodovia Régis Bittencourt (BR-116) foi bloqueada dezenas de vezes.
} 


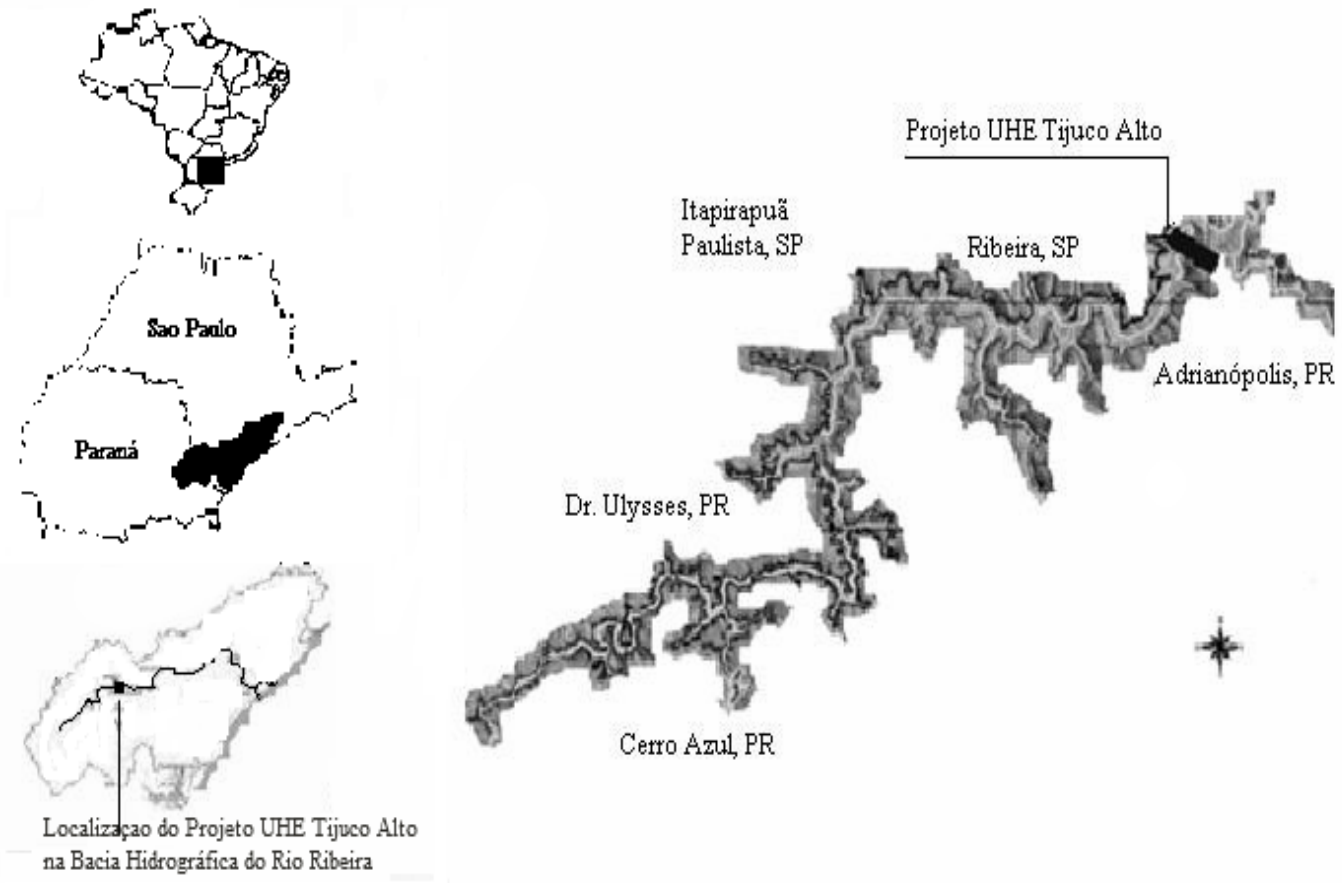

MAPA 1 - Localização da Bacia Hidrográfica do Rio Ribeira de Iguape e Área de Influência Direta do projeto UHE Tijuco Alto.

FONTE: CBA \& CNEC (2005a); ISA (2010). (Reconstruído).

$56,5 \mathrm{~km}^{2}$ e comprimento de $71,5 \mathrm{~km}$. As unidades territoriais que podem sofrer inundações pelo reservatório são Cerro Azul/PR, Adrianópolis/PR, Ribeira/ SP, Doutor Ulysses/PR, Itapirapuã Paulista/SP (CBA; CNEC, 2005a).

A Tabela 1 detalha as unidades territoriais ameaçadas pelo projeto UHE Tijuco Alto.

TABELA 1 - UNIDADE TERRITORIAL MUNICIPAL E ÁREA DO RESERVATÓRIO DO PROJETO UHE TIJUCO ALTO.

\begin{tabular}{|l|c|c|c|}
\hline Municípios & $\begin{array}{c}\text { Unidade } \\
\text { territorial } \\
\mathbf{( k m}^{\mathbf{2}}\end{array}$ & $\begin{array}{c}\text { População } \\
\text { municipal }\end{array}$ & $\begin{array}{c}\text { Área do } \\
\text { Reservatório } \\
\mathbf{( \% )}\end{array}$ \\
\hline Cerro Azul/PR & 1.341 & 16.527 & 36 \\
\hline Adrianópolis/PR & 1.349 & 5.799 & 19 \\
\hline Ribeira/SP & 335 & 3.151 & 18 \\
\hline Doutor Ulysses/PR & 781 & 6.631 & 17 \\
\hline Itapirapuã Paulista/SP & 406 & 3.775 & 10 \\
\hline
\end{tabular}

FONTE: CBA; CNEC (2005a).
A seguir as comunidades rurais identificadas na AID do projeto UHE Tijuco Alto.

Ilha Rasa/SP, Ilha Rasa/PR, Ouro Grosso, Rocha, Onças, Vila Brito, Criminosas, Córrego Grande, Corda Grande, Córrego Seco, Pinheirinho, Sete Quedas, Ribeirão do Canha, Bom Sucesso, Quarteirão dos Órfãos, Barra do Rio Ponta Grossa, Tigre, Balsa Velha, Ribeirão Bonito do Chapéu, Volta Grande, Casa Branca, Lajeadinho, Freguesia, Bomba (CBA; CNEC, 2005a).

\section{Método}

A pesquisa de campo foi iniciada em Cerro Azul/PR, a cidade mais atingida quando se considera a construção do projeto UHE Tijuco Alto. Segundo o IBGE (2006), entre os anos 1990 e 1999 as atividades econômicas de Cerro Azul estiveram caracterizadas pela lavoura temporária (arroz, 
batata-doce, cana-de-açúcar, feijão, mandioca, melancia, milho e tomate) e pela lavoura permanente (laranja, limão e maracujá). São atividades para abastecer o mercado e manter a subsistência.

O deslocamento esvazia as comunidades que desenvolviam as suas formas de subsistência e produz situações adversas para as famílias deslocadas. Esta pesquisa analisa o início do deslocamento populacional, os seus itinerários, os destinos e as formas atuais de subsistência das famílias deslocadas. Posteriormente, será desenvolvida análise sobre a crise econômica das comunidades rurais iniciada após os deslocamentos. A pesquisa de campo foi desenvolvida com aplicação de questionários e entrevistas junto aos proprietários de terras negociadas com a CBA e famílias não proprietárias de terras que desenvolviam atividades em propriedades negociadas.

A primeira etapa ocorreu em Cerro Azul/PR e foram aplicados 21 questionários. Por meio dos relatos desses entrevistados foram traçados os itinerários e os destinos dos interlocutores da segunda etapa da pesquisa, que foi produzida nos seguintes municípios: Colombo/PR, Bocaiúva do Sul/ PR, Rio Branco do Sul/PR, Doutor Ulysses/PR, Itaperuçu/ PR, Apiaí/SP, Capão Bonito/SP e Campina Monte Alegre/SP. Ao final da segunda etapa da pesquisa, foram adicionadas outras 25 entrevistas. Ao final da coleta de dados primários, foram entrevistadas 46 famílias em 9 cidades. ${ }^{10}$

\section{O processo de deslocamento}

O Boletim Informativo do Empreendimento UHE Tijuco Alto (CNEC, 2005) informa que houve apropriação de propriedades de 1988 até 1999 e desconhece a existência de mecanismos representativos da pressão para negociar a propriedade.

Foram localizadas, recentemente, 156 famílias que saíram da região e realizadas 46 entrevistas onde, em momento algum, foi mencionada truculência, violência ou coação na época da compra das propriedades, como querem fazer crer alguns críticos do empreendimento (CNEC, 2005).
Grupos civis organizados (Movimento dos Ameaçados por Barragens - MOAB, e o Sindicato da Agricultura Familiar do Vale do Ribeira - SINTRAVALE) e entidades defensoras do meio ambiente questionam o projeto hidrelétrico Tijuco Alto, bem como os mecanismos utilizados para apropriação de propriedades. A coleta de dados empíricos junto às pessoas e famílias envolvidas pela apropriação inicial de propriedades aponta a pressão como um dos procedimentos executados pela CBA. A seguir, os relatos que identificam tais procedimentos.

Os compradores da CBA iam de casa em casa à procura de proprietários para fazer oferta de compra. O povo não queria vender porque tinha linha de ônibus, posto de saúde, escola, armazém era povoado de muita gente [...]. CBA procurava na residência para forçar a venda, diziam que à água ia chegar e inundar tudo e quem não vendesse perderia a propriedade (PRADO $\left.{ }^{11}, 2006\right)$.

Segundo Jeremias (2006), os compradores da CBA diziam que quem não vendesse teria sua propriedade sob águas e, conforme Machado e Santos ${ }^{12}$ (2006):

Diziam que a água ia pegar tudo e se não vendessem a propriedade ela ia ficar sem valor. Até colocaram marca vermelha na casa para saber aonde à água ia bater. Desse jeito o caboclo fica com medo, nervoso e acaba vendendo (MACHADO; SANTOS, 2006).

Sereia (2006) aponta outros mecanismos da CBA para apropriação de propriedades:

Quando eu vendi para a CBA eu já residia e trabalhava na mineração em Colombo. Mas os funcionários da CBA iam até a firma para fazer oferta, para comprar e acabavam atrapalhando o meu serviço quando eu atendia eles. Como resultado eu tinha que pagar horas extras pelo tempo dedicado aos funcionários da CBA (SEREIA $\left.{ }^{13}, 2006\right)$.

\footnotetext{
${ }^{10}$ A pesquisa foi estendida até a cidade de Curitiba/PR para coletar dados no Instituto Paranaense de Desenvolvimento Econômico e Social - IPARDES - e no Instituto Brasileiro de Geografia e Estatística - IBGE. Portanto, foram 9 cidades visitadas para coleta de dados primários e uma para consultar arquivos, bibliotecas, informações de governo.

${ }^{11}$ Fixou residência na Comunidade Rural do Mato Preto.

${ }^{12}$ Fixou residência na Comunidade Rural Mangue.

${ }^{13}$ Fixou residência na Comunidade Rural do Mato Preto.
} 
Outro artifício da CBA, segundo Pontes ${ }^{14}$ (2006), foi o discurso de que tinha que vender e quem não vendesse na hora teria que vender quando a água chegasse e conforme os interesses de pagamento da CBA. Bestel e Bestel ${ }^{15}$ (2006) recordam que os funcionários da CBA divulgavam que bastava comprar $50 \%$ das propriedades para o reservatório e o governo compraria os outros $50 \%$, e quem não vendesse por um preço justo para a CBA, teria que vender por um preço menor para o Estado. O relato de Souza ${ }^{16}$ (2006) destaca a proposta de construção de uma fábrica de alumínio que geraria empregos para a região. Dentre as pressões exercidas para apropriação de propriedades em Dr. Ulysses/PR, segundo Brini ${ }^{17}$ (2006), está o discurso de que as propriedades teriam que ser vendidas mesmo e que quem não negociasse teria que retirar o dinheiro no cartório da cidade. As pressões pela apropriação de propriedades CBA foram intensas e diferenciadas. Dentre os resultados dessas pressões estão os deslocamentos involuntários, associados às rupturas e às transformações.

As informações colhidas ao longo da pesquisa de campo revelam que $100 \%$ da amostra nasceu, amadureceu e constituiu família na região. Além disso, em comunidades rurais, é comum a presença dos laços de parentescos não consanguíneos. As tipologias de relações identificadas entre proprietários e não proprietários foram as seguintes:

- Tipologia A - relações de parentescos não consanguíneas: irmão de criação, genro e compadrio (padrinho de nascimento e de casamento);

- Tipologia B - relações de trabalho: meeiros e arrendatários.

Para Martins (1991, p. 31), a migração expropria, desenraiza e proletariza o camponês. Além disso, continua Martins, o mundo de relações sociais campesinas é rompido para lançá-lo no mundo das relações contratuais, nas relações revolucionárias da condição operária. Neste sentido, o deslocamento é uma transição forçada do proletariado passivo para o ativo e, além disso, a ela está associada a impossibilidade da escolha do próprio destino, ou seja, o deslocado, de modo geral, se estabelece no espaço que convier e não naqueles escolhidos e planejados.

\footnotetext{
${ }^{14}$ Fixou residência na Comunidade Rural do Mato Preto.

${ }^{15}$ Fixou residência na Comunidade Rural do Bom Sucesso.

${ }^{16}$ Fixou residência na Comunidade Rural do Mato Preto.

${ }^{17}$ Fixou residência na Comunidade Rural Barra do Rio do Tigre.

${ }^{18}$ A não negociação da propriedade de terras não anula a ação da CBA na região.
}

\section{O deslocamento para famílias não proprietárias de terras}

São consideradas famílias não proprietárias de terras atingidas e deslocadas aquelas que: A) despendiam força de trabalho em propriedades negociadas com a CBA e foram deslocadas, e B) despendiam força de trabalho em propriedades não negociadas com a $\mathrm{CBA}$ e permanecem na propriedade sem sofrer deslocamento. ${ }^{18} \mathrm{~A}$ inexistência do deslocamento não invalida a particularidade família atingida pelo processo de apropriação de propriedades. A não negociação, no caso "B", conforme coleta de dados primários, conduz à manutenção da propriedade em condições inferiores ao período que antecede o processo de apropriações, seguida de reduzidas condições de subsistência das famílias proprietárias e daquelas não proprietárias, não deslocadas mas atingidas. A não negociação, ainda no caso "B", também significa o deslocamento das famílias não proprietárias por conta da dificuldade do proprietário em manter a propriedade economicamente ativa.

Foi identificada a distância intermunicipal percorrida para cada família deslocada. Foram consultadas 17 famílias não proprietárias de terras durante a coleta de dados primários.

A Tabela 2 apresenta os deslocamentos humanos para famílias não proprietárias de terras.

As famílias não proprietárias deslocadas no interior do próprio município tem as seguintes representações. $\mathrm{Na}$ Tabela 2, para 7 famílias não proprietárias de terras, existe fixação da residência na cidade de Cerro Azul/PR. Este indicador representa a escolha do espaço para viver, portanto, a ruptura das sociabilidades para os itinerários internos aos limites municipais de Cerro Azul/PR apresenta menor intensidade quando comparada aos deslocamentos intermunicipais e interestaduais. Foi iniciado processo de favelização no Jardim Eliane, bairro urbano de Cerro Azul, para abrigar as famílias deslocadas pelo projeto.

Os significados para os deslocamentos intermunicipais são os seguintes:

- Dificuldades com inserção social (reconstruir sociabilidade rompida com o processo de deslocamento); 
JERONYMO, A. C. J.; BERMANN, C.; GUY-GUERRA, S. M. Deslocamentos, itinerários e destinos de populações...

TABELA 2 - DESLOCAMENTO HUMANO PARA FAMÍLIAS NÃO PROPRIETÁRIAS.

\begin{tabular}{|c|c|c|c|c|c|}
\hline - & $\begin{array}{c}\text { Comunidades } \\
\text { na AID }\end{array}$ & D 1 & D 2 & D 3 & $\mathbf{k m ~ P}$ \\
\hline 1 & Barra do Turvo & Cerro Azul/PR & & & SDI \\
\hline 2 & Mato Preto & Cerro Azul/PR & & & SDI \\
\hline 3 & Mato Preto & Colombo/PR & Bocaiúva do Sul/PR & Cerro Azul/SP & 171,4 \\
\hline 4 & São Francisco & Cerro Azul/PR & Cerro Azul/PR & & SDI \\
\hline 5 & Ribeirão do Rocha & Cerro Azul/PR & & & SDI \\
\hline 8 & Bom Sucesso & Colombo/PR & Itaperuçu/PR & & 78,6 \\
\hline 9 & Mato Preto & Colombo/PR & & & 78,6 \\
\hline 10 & Brum & Cerro Azul/PR & & & SDI \\
\hline 11 & Ribeira & Cerro Azul/PR & & & SDI \\
\hline 16 & São Francisco & Capão Bonito/SP & Campina Monte Alegre/SP & & 280,3 \\
\hline 17 & São Francisco & Cerro Azul/PR & & & SDI \\
\hline
\end{tabular}

FONTE: Pesquisa de campo.

${ }^{1}$ Proprietário não negociou a propriedade. Permanece na propriedade 1 (uma) família não proprietária de terras.

$\mathrm{D}=$ Deslocamento. $\mathrm{km} \mathrm{P}=$ Quilômetros Percorridos (da AID até o último deslocamento). SDI = Sem Deslocamento Intermunicipal.

- Inserção profissional onde convier, ou seja, percorrer diferentes regiões em busca de trabalho para a manutenção da subsistência pessoal e familiar.

Quando o deslocamento inicial (D1) não é direcionado para Cerro Azul/PR a conclusão é a potencialidade para novo deslocamento. A dificuldade para a recomposição das sociabilidades após o deslocamento intermunicipal é maior quando comparada aos deslocamentos internos.

Para a Tabela 2, o deslocamento . $^{\circ} 1$ representa percurso entre $50 \mathrm{~km}$ e $100 \mathrm{~km}$, isto é, quando é considerada a distância entre Cerro Azul/PR e a cidade que finaliza o deslocamento. Para a menor parcela desta amostra, o deslocamento . $^{\circ} 1$ atinge percurso de até $210 \mathrm{~km}$. No deslocamento . $^{\circ} 2$, o percurso oscila entre $54,4 \mathrm{~km}$, até Rio Branco do Sul/PR, e 78,6 km, até Colombo/PR. Ainda na Tabela 2, uma das famílias do deslocamento n. $^{\circ} 2$ percorreu $281 \mathrm{~km}$ a partir da cidade de Cerro Azul/PR.

Dentre os resultados da não identificação do não proprietário de terras como portador de direitos, segundo informações do Instituto Socioambiental (2010), está o passivo social, equivalente a 228 famílias de meeiros, arrendatários, parceiros ou posseiros largados à própria sorte ao serem expulsos das terras onde viviam e trabalhavam sem qualquer tipo de recompensa quando a CBA iniciou apropriação de propriedades de terras ao longo dos primeiros 15 anos do projeto Tijuco Alto. A última versão do projeto UHE Tijuco Alto firma compromisso com o reassentamento rural para famílias não proprietárias de terras que permanecem na AID.

Existe na área do projeto uma população composta por 312 famílias de não proprietários e 266 de proprietários. Os principais beneficiários deste reassentamento serão os não proprietários que englobam arrendatários, meeiros, parceiros e filhos de proprietários que constituem famílias independentes financeiramente dos pais, que moram e trabalham na terra. O programa de reassentamento prevê além da terra, construção de casa nova, rede de energia, abastecimento de água, saneamento e acesso, além de assistência técnica para produção (CNEC, 2007).

A compensação dos não proprietários inclusos na AID reduz a extensão do passivo social futuro do projeto UHE 
Tijuco Alto. Entretanto, é inegável a existência do passivo social identificado nas primeiras apropriações de terras, bem como os rompimentos e fraturas nos laços de sociabilidades ocorridos ao longo dos deslocamentos.

\section{O deslocamento para famílias proprietárias de terras}

As famílias negociaram (integral ou parcial) a propriedade de terras com a CBA. A pesquisa contou com a contribuição de 29 famílias proprietárias de terras, apresentadas na Tabela 3.

Para as famílias proprietárias existe a possibilidade de negociação da propriedade ${ }^{19}$, ao passo que para os não proprietários sobrou o deslocamento compulsório. A negociação da propriedade pode representar a possibilidade para adquirir outra propriedade próxima aos amigos e parentes, portanto, no espaço onde é despertado o interesse e não naquele que convier. Desta forma, as rupturas na sociabilidade são reduzidas, todavia, não podem ser eliminadas.

TABELA 3 - DESLOCAMENTO HUMANO PARA FAMÍLIAS PROPRIETÁRIAS DE TERRAS.

\begin{tabular}{|c|c|c|c|c|c|}
\hline-- & Comunidades na AID & D 1 & D 2 & D 3 & km P \\
\hline 1 & Mato Preto & Colombo/PR & & & 78,6 \\
\hline 2 & Mato Preto & Cerro Azul/PR & Rio Branco do Sul/PR & & 54,4 \\
\hline 3 & Mato Preto & Colombo/PR & Colombo/PR & & 78,6 \\
\hline 4 & Mato Preto & Nova Esperança/PR & Rio Branco do Sul/PR & & 955 \\
\hline 5 & Ribeirão do Tigre & Colombo/PR & Bocaíuva do Sul/PR & & 103,2 \\
\hline 6 & Mato Preto & Capão Bonito/SP & Colombo/PR & & 451 \\
\hline 7 & Turvo & Cerro Azul/PR & & & SDI \\
\hline 8 & Ribeira & Ribeira/SP & Adrianópolis/PR & Cajati/SP ${ }^{1}$ & 408,5 \\
\hline 9 & São Francisco & Capão Bonito/SP & & & 209 \\
\hline 10 & Mato Preto & Capão Bonito/SP & & & 209 \\
\hline 11 & São Francisco & Cerro Azul/PR & & & SDI \\
\hline 12 & São Francisco & Cerro Azul/PR & & & SDI \\
\hline 13 & Ribeirão do João Gordo & Cerro Azul/PR & & & SDI \\
\hline 14 & Mato Preto & Cerro Azul/PR & & & SDI \\
\hline 15 & Mato Preto & Cerro Azul/PR & & & SDI \\
\hline 16 & Ribeirão do Severo & Cerro Azul/PR & & & SDI \\
\hline 17 & Bom sucesso & Cerro Azul/PR & & & SDI \\
\hline 18 & Córrego Seco & Cerro Azul/PR & & & SDI \\
\hline 19 & Mato Preto & Cerro Azul/PR & & & SDI \\
\hline 20 & Mato Preto & Cerro Azul/PR & & & SDI \\
\hline 21 & Mato Preto & Cerro Azul/PR & & & SDI \\
\hline 22 & Casa Branca & Cerro Azul/PR & & & SDI \\
\hline 23 & Quarteirão dos Órfãos & Cerro Azul/PR & & & SDI \\
\hline 24 & Bom sucesso & Cerro Azul/PR & & & SDI \\
\hline 25 & Ribeirão do João Gordo & Cerro Azul/PR & & & SDI \\
\hline 26 & Barra do Tigre ${ }^{2}$ & & & & SDI \\
\hline 27 & Mato Preto & Cerro Azul/PR & & & SDI \\
\hline 28 & Casa Branca & Cerro Azul/PR & & & SDI \\
\hline 29 & Barra do rio Ponta Grossa & Cerro Azul/PR & & & SDI \\
\hline
\end{tabular}

FONTE: Pesquisa de campo.

${ }^{1}$ A comunidade de Ribeira fica na cidade de Ribeira/SP. Esta família promoveu um quarto deslocamento para a cidade de Apiaí/SP.

${ }^{2}$ Proprietário não negociou a propriedade e abandonou as atividades da propriedade.

$\mathrm{D}=$ Deslocamento. $\mathrm{km} \mathrm{P}=$ Quilômetros percorridos (da AID até o último deslocamento). SDI = Sem Deslocamento Intermunicipal.

\footnotetext{
${ }^{19}$ Esta autonomia é relativa. Já apontamos em momento anterior do trabalho os métodos utilizados para apropriação de propriedades. O medo, o pavor, a tensão e a pressão são mecanismos que preveem a destituição da autonomia e são mecanismos usuais para apropriação de propriedades.
} 
Negociar a propriedade não necessariamente representa a oportunidade para adquirir outra. Segundo Pontes (2006), "o dinheiro pago pela propriedade não foi o suficiente para comprar a casa atual, e eu tive que emprestar do banco para completar". Quando o proprietário rural não sobrevive do trabalho na própria propriedade - pelo tamanho reduzido -, de modo geral, a sua força de trabalho é despendida em propriedades vizinhas (plantando, colhendo, limpando terreno, cuidando de animais etc.). Ter que negociar a propriedade, neste caso, pode representar a dificuldade para adquirir outro imóvel, a migração indesejada seguida de rupturas nos laços de sociabilidades e a aproximação deste proprietário em relação aos não proprietários expulsos das propriedades negociadas.

Para 6 famílias que conformam o deslocamento $\mathrm{n}^{\circ}$ 2 da tabela 3, uma fixou residência na cidade de Cerro Azul/PR. Esta informação, novamente, conduz à seguinte interpretação: quando o primeiro deslocamento segue o itinerário exterior aos limites municipais - da cidade onde a sociabilidade é mais fértil, mais intensa, mais íntima -, os deslocamentos n. ${ }^{\circ} 2$ e o n. ${ }^{\circ} 3$ da tabela 3 são fortalecidos, isto quando comparados aos deslocamentos municipais.

O deslocamento espacial das famílias proprietárias de terras é semelhante ao deslocamento dos não proprietários. No deslocamento n. ${ }^{\circ} 1$, o menor itinerário foi percorrido até a cidade de Colombo, 78,6 km de Cerro Azul/PR, e o maior foi até Nova Esperança do Sul/PR, distante $464 \mathrm{~km}$. No segundo deslocamento, a amostra com o menor itinerário finaliza em Rio Branco do Sul/PR, distante 54,5 km de Cerro Azul/PR, e a maior é Colombo/PR, com os seus 78,6 km.

O deslocamento . $^{\circ} 1$ da tabela 3 indica que 20 famílias proprietárias fixaram residência no perímetro municipal de Cerro Azul/PR e apenas uma produziu o deslocamento n. ${ }^{\circ}$ 2. Este dado reflete a capacidade de integração das famílias deslocadas (social, econômica e cultural) na cidade de Cerro Azul/PR. Nos deslocamentos n. ${ }^{\circ} 2$ e n. ${ }^{\circ} 3$ não existe o retorno para Cerro Azul/PR.

\section{A economia das comunidades ribeirinhas e as condições de subsistência após os deslocamentos}

\section{A desestruturação econômica comunitária}

Outro reflexo dos deslocamentos é a desestruturação econômica. Foram aplicadas entrevistas com antigos comerciantes das comunidades ribeirinhas esvaziadas pelo deslocamento humano. O diagnóstico para a crise na economia rural regional é a ausência dos consumidores. O deslocamento está associado à redução das receitas das casas comerciais (bar, mercearia, secos e molhados etc.) e à desestruturação econômica regional, conforme os relatos que se seguem.

Sobre o momento posterior ao início da apresentação do projeto UHE Tijuco Alto.

Após apresentação do projeto $^{20}$, as propriedades são compradas, meeiros e arrendatários começam a sair da propriedade, inicia retirada do local e cada um segue seu rumo. Como consequência diminui o número de clientes e as vendas no comércio. São cerca de 20 anos com vendas em queda (ELISEU $\left.{ }^{21}, 2006\right)$.

Houve redução do contingente populacional da maior comunidade rural da região. Um dos reflexos desta redução foi sentido pelos comerciantes das comunidades rurais.

Em termos de mão de obra ficou tudo parado. Quem tinha comércio parou, simplesmente fechou. Quem precisava do trabalho do meeiro fechou, simplesmente fechou (SILVA ${ }^{22}$, 2006).

Segundo Paulista:

Os principais clientes saem da região e inicia a crise do comércio nas comunidades [...] O Olívio Faria tinha armazém na ponta da Ribeira e hoje varre rua para pre-

\footnotetext{
${ }^{20}$ A referência é o projeto UHE Tijuco Alto.

${ }^{21}$ Fixou residência na Comunidade Rural do Mato Preto.

${ }^{22}$ Fixou residência na Comunidade Rural do Mato Preto.
} 
feitura, varre a praça principal. Vendeu a terra porque o comércio parou (PAULISTA ${ }^{23}, 2006$ ).

Sobre o esvaziamento da comunidade do Mato Preto durante a década de 1990: "No Mato Preto moravam cerca de 1.100 pessoas" (ELISEU $\left.{ }^{24}, 2006\right)$ e hoje "[...] a Comunidade do Mato Preto tá deserta, tá horrível, só tem casinha velha" (MANGUER $\left.{ }^{25}, 2006\right)$. O processo de apropriação de propriedades, portanto, provocou modificações nos ambientes comunitário e familiares.

\section{Trabalho, renda e infraestrutura residencial para não proprietários de terras}

As modificações nas formas de subsistências para as famílias não proprietárias de terras são apresentadas na Tabela 4.

TABELA 4 - SUBSISTÊNCIA PARA FAMÍLIAS NÃO PROPRIETÁRIAS DE TERRAS APÓS O DESLOCAMENTO

\begin{tabular}{|c|c|c|c|}
\hline \multirow{4}{*}{ Anteriormente } & \multicolumn{2}{|c|}{ Atualmente } & Total \\
\hline \multirow{4}{*}{$\begin{array}{c}\text { Famílias não } \\
\text { proprietárias de terras }\end{array}$} & Aposentado & Aposentado & 5 \\
\cline { 2 - 4 } & Proprietário & Comerciante & 1 \\
\cline { 2 - 4 } & Assalariado & Folguista & 4 \\
\cline { 2 - 4 } & Do lar & Do lar & 2 \\
\cline { 2 - 4 } & Costureira & Costureira & 1 \\
\cline { 2 - 4 } & Trabalhador rural & Meeiro & 3 \\
& & Por dia & 1 \\
\hline
\end{tabular}

FONTE: Pesquisa de campo.

$\mathrm{Na}$ Tabela 4, parcela dos não proprietários de terras sobrevive da aposentadoria rural, fato que reflete a importância deste benefício. Uma vez que o lavrador envelhece, as forças e a agilidade para o desempenho da atividade agrícola reduzem e, além disso, a aposentadoria é uma "segurança" para a manutenção da subsistência. Restou para o trabalhador rural não aposentado negociar a força de trabalho para manutenção da subsistência pessoal e familiar. O não proprietário de terras não necessariamente desempenha atividades rurais após o deslocamento. Isto é decorrente da própria condição para a transição operária, ou seja, não é escolhida a cidade para trabalhar e nem a atividade a ser desenvolvida, a política é aceitar onde houver trabalho. O mais importante é a manutenção da subsistência e não necessariamente despender esforços em atividade que esteja mais próxima da experiência, do gosto e do próprio interesse.

As considerações sobre o elemento renda foram substancialmente modificadas após o processo de deslocamento. A amostra a seguir aponta as modificações relacionadas à renda:

- 6 famílias não proprietárias identificam mudanças substanciais no elemento renda após o deslocamento, seguidas do aumento na capacidade de consumo;

- 6 famílias não proprietárias não identificam modificações substanciais na renda após o deslocamento;

- 5 famílias não proprietárias identificam mudanças substanciais na renda após o deslocamento, seguidas de restrições para manter a capacidade de consumo familiar anterior ao deslocamento.

O elemento renda reduzida interfere na aquisição da cesta básica alimentar. $\mathrm{O}$ contexto posterior ao deslocamento incorpora novas modalidades para a aquisição de alimentos. Anterior ao deslocamento, as famílias não proprietárias criavam animais (gado leiteiro, gado de corte, cabra, porco), aves (galinha, pavão, pato) e cultivavam (hortaliças e frutas). As modificações na cesta básica alimentar, ocorridas após o deslocamento, transformam os agricultores que produzem e criam para a subsistência em consumidores. Portanto, a redução do orçamento familiar poderá afetar, negativamente, a capacidade para adquirir alimentos a partir da relação comercial. Em contraposição, a satisfação com o elemento renda estabelece aproximações com a capacidade para adquirir bens de consumo, conforme apresenta a Tabela 5.

Os valores apresentados na Tabela 5 apontam maior capacidade de consumo de equipamentos eletrodomésticos e eletroeletrônicos, os quais representam:

- Parcela da amostra fixa residência em casa cedida pelo empregador. Este fato anula os seguintes custos: aluguel, consumo de água, consumo de eletricidade, impostos. $\mathrm{O}$ custo mensal para manutenção da subsistência familiar diminui e proporciona maior capacidade de consumo;

\footnotetext{
${ }^{23}$ Fixou residência na Comunidade Rural do Mato Preto.

${ }^{24}$ Fixou residência na Comunidade Rural do Mato Preto.

${ }^{25}$ Fixou residência na Comunidade Rural do Mato Preto.
} 
TABELA 5 - CONSUMO DE ELETRODOMÉSTICOS E ELETROELETRÔNICOS PARA FAMÍLIAS NÃO PROPRIETÁRIAS DE TERRAS.

\begin{tabular}{|c|c|c|}
\hline Eletrodoméstico & $\begin{array}{c}\text { Antes do } \\
\text { deslocamento }\end{array}$ & Após o deslocamento \\
\hline Fogão a gás & - & 10 \\
\hline Aparelho de som & - & 12 \\
\hline TV & 1 & 14 \\
\hline Geladeira & 1 & 14 \\
\hline Rádio elétrico & - & 16 \\
\hline Lanterna & 2 & - \\
\hline Rádio de pilha & 11 & 6 \\
\hline Máquina de lavar & - & 10 \\
\hline Lampião & 2 & - \\
\hline Outros & - & 8 \\
\hline
\end{tabular}

FONTE: Pesquisa de campo.

Outros: Video game, forninho, ferro de passar, freezer, tanquinho, liquidificador, telefone fixo e telefone celular, aparelho DVD.

- Parcela da amostra fixa residência em casa cedida por parentes. Este fato anula o custo com aluguel e proporciona maior capacidade de consumo;

- Quando os filhos deixam de residir com os pais após o deslocamento, a renda familiar mensal é dedicada integralmente para o pai e a mãe. Tal fato proporciona maior capacidade de consumo;

- O deslocamento para as famílias que conseguiram inserção profissional representa acréscimo substancial na renda e maior poder de consumo.

A Tabela 6 apresenta as informações sobre o abastecimento de água.

TABELA 6 - ABASTECIMENTO DE ÁGUA DAS RESIDÊNCIAS DE FAMÍLIAS NÃO PROPRIETÁRIAS DE TERRAS (UNIDADE FAMILIAR).

\begin{tabular}{|c|c|c|}
\hline $\begin{array}{c}\text { Procedência da } \\
\text { água }\end{array}$ & Antes do deslocamento & Após o deslocamento \\
\hline Nascente & 8 & 3 \\
\hline Rio & 8 & 1 \\
\hline RAP & 1 & 9 \\
\hline Nascente / Rio & - & 4 \\
\hline
\end{tabular}

FONTE: Pesquisa de campo.

RAP: Rede de Abastecimento Público.

A Tabela 7 apresenta as informações sobre o destino dos efluentes.
TABELA 7 - DESTINO DOS EFLUENTES RESIDÊNCIAS PARA AS FAMÍLIAS NÃO PROPRIETÁRIAS DE TERRAS (UNIDADE FAMILIAR).

\begin{tabular}{|c|c|c|}
\hline Destino dos efluentes & $\begin{array}{c}\text { Antes do } \\
\text { deslocamento }\end{array}$ & $\begin{array}{c}\text { Após o } \\
\text { deslocamento }\end{array}$ \\
\hline Buraco & 3 & - \\
\hline Rio & 5 & 3 \\
\hline Mato & 5 & 9 \\
\hline Fossa rudimentar & 3 & 9 \\
\hline Valeta & 1 & 1 \\
\hline Fossa séptica & - & 3 \\
\hline Rede geral de esgoto & - & 1 \\
\hline
\end{tabular}

FONTE: Pesquisa de campo.

A tipologia do material para construção civil residencial é representada no Gráfico 1.

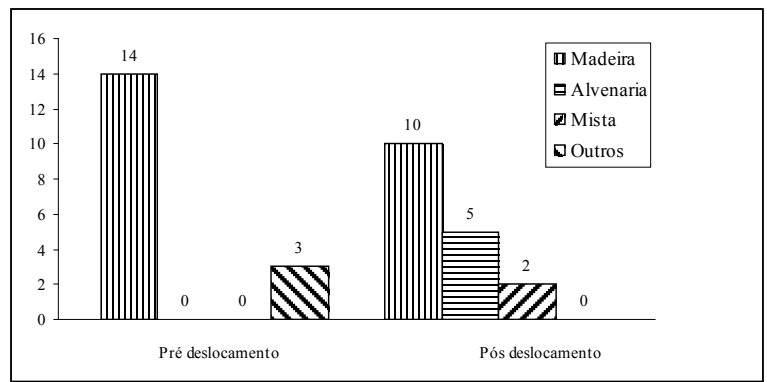

GRÁFICO 1 - Tipologia do material de construção civil para residências de famílias não proprietárias de terras (unidade familiar).

FONTE: Pesquisa de campo.

Mista: madeira e alvenaria. Outros: sapé, capim, barro.

Embora parcela da amostra de família não proprietária aponte piora no elemento renda, isto não indica redução da capacidade para comprar equipamentos eletrodomésticos, eletroeletrônicos e promover modificações na tipologia do material de construção civil residencial.

\section{Trabalho, renda e infraestrutura residencial para familias que negociaram a propriedade de terras}

Os reflexos dos deslocamentos nas relações de trabalho, renda e infraestrutura residencial para as famílias que negociaram a propriedade de terras apresentam modificações. A Tabela 8 estratifica o grupo de proprietários de terras e apresenta as formas de subsistência após o deslocamento. 
JERONYMO, A. C. J.; BERMANN, C.; GUY-GUERRA, S. M. Deslocamentos, itinerários e destinos de populações...

TABELA 8 - SUBSISTÊNCIA PARA FAMÍLIAS PROPRIETÁRIAS DE TERRAS APÓS O DESLOCAMENTO

\begin{tabular}{|c|c|c|c|}
\hline Anteriormente & \multicolumn{2}{|c|}{ Atualmente } & Total \\
\hline \multirow{4}{*}{} & Aposentado & Aposentado & 9 \\
\cline { 2 - 4 } & Proprietário & Comerciante & 5 \\
& & Produtor rural & 4 \\
\cline { 2 - 4 } Famílias que & Arrendatário & Arrendatário & 1 \\
\cline { 2 - 4 } negociaram a & & Folguista & 2 \\
propriedade de & & Meeiro & 1 \\
terras & Assalariado & Costureira & 1 \\
& & Técnico em & 1 \\
& & eletrônica & \\
& & Doméstica & 1 \\
& & Pedreiro & 1 \\
& & Serralheiro & 1 \\
& & Servente & 1 \\
\cline { 2 - 4 } & Desempregado & Desempregado & 1 \\
\hline
\end{tabular}

FONTE: Pesquisa de campo.

Para a Tabela 8 , os aposentados (equivalente a $1 / 3$ da amostra) e os proprietários (equivalente a $1 / 3$ da amostra), conjuntamente, representam 18 das 29 famílias entrevistadas, o que, nesta análise, permite fazer valer a condição de ex-proprietário de terras no processo de aquisição de propriedades após o deslocamento. Neste grupo, está presente a disponibilidade para escolher o que fazer e onde fazer. Entretanto, tal situação é contraposta às outras 10 amostras das 29 existentes. Isto porque a posição do ex-proprietário não demonstrou suficiência para impedir o trânsito para a condição assalariada. Ainda neste grupo de ex-proprietários está o desempregado (1) que não subsiste do salário e integra os diferentes aspectos da marginalização.

Ainda na Tabela 8 é possível considerar os problemas que contribuem para reduzir a possibilidade de recomposição familiar e manutenção da subsistência após o deslocamento. Tal fato, possivelmente, encontra diagnóstico no tamanho da propriedade negociada. Quanto maior o tamanho da propriedade, maior será o montante de recursos adquiridos e, portanto, haverá menor dificuldade para a escolha e identificação dos espaços e das formas para manutenção da subsistência. Em contraposição, quanto menor o tamanho da propriedade negociada, menor será o montante de recursos adquiridos e, consequentemente, será maior a dificuldade para escolher novos espaços e formas para a reprodução da subsistência pessoal e familiar. Isto significa dizer que o processo de apropriação de propriedades para construção das obras hidrelétricas transforma e transporta pequenos proprietários de terras, famílias que subsistem da própria propriedade, para a lógica da negociação da força de trabalho com um empregador qualquer, que pode ser na indústria, no comércio ou na lavoura.

Sobre a renda após o deslocamento, a amostra aponta a diversidade de modificações:

- 10 famílias proprietárias identificam mudanças substanciais na renda após o deslocamento, seguidas do aumento na capacidade de consumo;

- 7 famílias proprietárias não identificam modificações substanciais na renda após o deslocamento;

- 12 famílias proprietárias identificam mudanças substanciais na renda após o deslocamento, seguidas de restrições para manter a capacidade de consumo familiar anterior ao deslocamento.

A Tabela 9, a seguir, apresenta o abastecimento de água.

TABELA 9 - ABASTECIMENTO DE ÁGUA PARA RESIDÊNCIAS DE FAMÍLIAS PROPRIETÁRIAS DE TERRAS (UNIDADE FAMILIAR).

\begin{tabular}{|c|c|c|}
\hline Procedência da água & $\begin{array}{c}\text { Antes do } \\
\text { deslocamento }\end{array}$ & $\begin{array}{c}\text { Após o } \\
\text { deslocamento }\end{array}$ \\
\hline Nascente & 19 & - \\
\hline Rio & 7 & - \\
\hline RAP & 1 & - \\
\hline Nascente /poço & 1 & 1 \\
\hline Poço & 1 & 1 \\
\hline Rede /poço & - & 1 \\
\hline Poço/água engarrafada & - & \\
\hline
\end{tabular}

FONTE: Pesquisa de campo.

RAP: Rede de Abastecimento Público.

A Tabela 10, a seguir, apresenta o destino dos efluentes.

TABELA 10 - DESTINO DOS EFLUENTES PARA RESIDÊNCIAS DE FAMÍLIAS PROPRIETÁRIAS DE TERRAS (UNIDADE FAMILIAR).

\begin{tabular}{|c|c|c|}
\hline Destino dos efluentes & $\begin{array}{c}\text { Antes do deslo- } \\
\text { camento }\end{array}$ & $\begin{array}{c}\text { Após o desloca- } \\
\text { mento }\end{array}$ \\
\hline Fossa rudimentar & 15 & 11 \\
\hline Buraco, mato, outro terreno & 7 & 1 \\
\hline Rio & 2 & - \\
\hline Valeta & 2 & - \\
\hline Rede geral de esgoto & - & 4 \\
\hline Fossa séptica & 2 & 13 \\
\hline Caixa de coleta ${ }^{1}$ & 1 & - \\
\hline
\end{tabular}

FONTE: Pesquisa de campo.

${ }^{1}$ Parte do esgoto é canalizado. 
O Gráfico 2, a seguir, apresenta a tipologia para infraestrutura do material residencial.

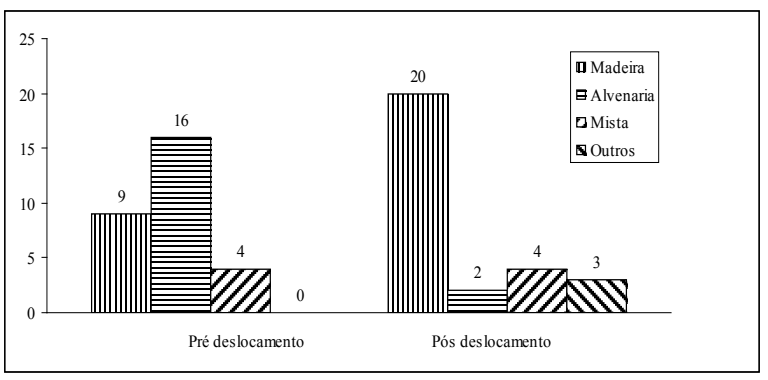

GRÁFICO 2 - Tipologia do material de construção civil para residência das famílias proprietárias de terras (unidade domiciliar).

FONTE: Pesquisa de campo.

Mista: madeira e alvenaria. Outros: sapé, capim, barro.

A Tabela 11 apresenta o consumo de eletrodomésticos e eletroeletrônicos.

Existe aumento na aquisição de equipamentos eletrodomésticos e eletroeletrônicos. Para o período posterior ao deslocamento, a amostra aponta a presença de equipamentos que economizam energia humana (a máquina de lavar, o tanquinho e a centrífuga), viabilizam as comunicações localizadas, globalizadas e o entretenimento (aparelho de som, o rádio, o videocassete, o DVD, o telefone fixo, o televisor e o computador).
O consumo desses equipamentos está associado à fixação de residência na sede municipal e não nas comunidades rurais. Fixar residência na sede municipal tem os seus custos. A aquisição de equipamentos eletrodomésticos e eletroeletrônicos representa aumento no consumo de eletricidade e, portanto, na conta de consumo de eletricidade. Além desses custos, existem outros. A água, por exemplo, proveniente da Rede de Abastecimento de Público, e a infraestrutura para saneamento público representam novas despesas para as famílias deslocadas da zona rural. Tais custos consomem parcela significativa da renda das famílias que negociaram a propriedade de terras. Assim sendo, a renda ficará reduzida devido ao aumento no custo de vida mensal, após agregar os serviços.

\section{Conclusões}

A amostra utilizada na pesquisa de campo contou com 29 famílias proprietárias de terras e 17 não proprietárias. A diferença entre esses valores é creditada à incerteza sobre o destino das famílias não proprietárias de terras, o que reduz a possibilidade de identificá-las, ao passo que parcela das famílias proprietárias fixa residência na cidade de Cerro Azul/PR, princípio da pesquisa de campo. Com relação ao deslocamento, ao comparar as famílias proprietárias e não proprietárias de terras, as primeiras têm maiores oportunidades para ocupar o espaço de interesse e, desta maneira,

TABELA 11 - CONSUMO DE ELETRODOMÉSTICOS E ELETROELETRÔNICOS PARA FAMÍLIAS PROPRIETÁRIAS DE TERRAS.

\begin{tabular}{|c|c|c|c|c|c|}
\hline Eletrodoméstico & $\begin{array}{c}\text { Antes do } \\
\text { deslocamento }\end{array}$ & $\begin{array}{c}\text { Após o } \\
\text { deslocamento }\end{array}$ & Eletrodoméstico & $\begin{array}{c}\text { Antes do } \\
\text { deslocamento }\end{array}$ & $\begin{array}{c}\text { Após o } \\
\text { deslocamento }\end{array}$ \\
\hline Parabólica & 2 & - & Ventilador & 3 & 4 \\
\hline Rádio de pilha & 27 & 12 & Vídeo & - & 4 \\
\hline Rádio elétrico & 9 & 22 & DVD & - & 4 \\
\hline TV & 6 & 25 & Telefone fixo & - & 14 \\
\hline Geladeira & 10 & 28 & Máquina de lavar & - & 16 \\
\hline Lanterna & 4 & - & Computador & - & 3 \\
\hline Lampião & 3 & - & Forninho & - & 3 \\
\hline Fogão a gás & 8 & 20 & Tanquinho & - & 3 \\
\hline Lamparina & 1 & - & Centrifuga & - & 3 \\
\hline Aparelho de som & 7 & 17 & Micro-ondas & - & 5 \\
\hline Liquidificador & 6 & 11 & Freezer & - & 2 \\
\hline Batedeira & 5 & 20 & Outros & - & 28 \\
\hline Ferro de passar & 4 & 8 & - & - & - \\
\hline
\end{tabular}

FONTE: Pesquisa de campo.

Outros: Celular, fogão a lenha, massageador elétrico, máquina de cortar grama, cafeteira, aspirador de pó, máquina de costura. 
diminuir a tensão, a dor e os problemas produzidos pela ruptura nos laços de sociabilidade. O grupo não proprietário, por sua vez, sofre maior quantidade de deslocamentos porque não possui propriedade de terras, mas apenas a força de trabalho. Entretanto, possuir a força de trabalho, para a amostra apresentada, não é suficiente para reduzir a extensão dos itinerários percorridos, logo, nesta situação, existe propensão para o rompimento dos laços de sociabilidade.

Com relação ao desenvolvimento regional decorrente do projeto UHE Tijuco Alto, o mesmo não aconteceu. Isto não significa dizer que a CBA não atuou no espaço cobiçado. Pelo contrário, a pesquisa demonstrou que a CBA atuou, expropriou, deslocou (proprietários e não proprietários) pessoas, famílias e comunidades inteiras. Essas ações influenciaram e influenciam nos mecanismos para reter a dinamização da economia regional e na insegurança em iniciar investimentos (públicos e privados) em município com o histórico da possibilidade ou impossibilidade de construção de UHE.

Os deslocamentos, de modo geral, têm os destinos finalizados nas pequenas e médias cidades. Neste sentido, não é possível defender o posicionamento de que os deslocamentos originados pela apropriação de terras para construir UHE são finalizados nas grandes cidades e contribuem para haver concentração urbana, conforme os tradicionais fluxos migratórios (do rural para o urbano). Na verdade, com relação aos municípios com reduzidos contingentes populacionais, conforme a amostra, eles absorvem parcelas significativas das famílias deslocadas e a presença de migrantes inesperados pode comprometer a infraestrutura para o fornecimento de serviços públicos essenciais na cidade.

$\mathrm{O}$ deslocamento apresenta contraste que necessita consideração. O deslocamento seguido da inserção em alguma atividade de subsistência na lavoura ou como operário(a) provoca aumento na capacidade de consumo de equipamentos eletrodomésticos e eletroeletrônicos e melhoria na infraestrutura residencial (saneamento, material para construção civil). Essas conquistas materiais não podem ser identificadas como uma possível superação e anulação das mazelas decorrentes do deslocamento. As conquistas materiais não permitem subtrair conflitos, tensões, histórias de lutas e disputas, situações típicas de quem foi retirado de um lugar e lançado para outro e, assim sendo, ter que recompor sociabilidades, a vida econômica e a vida profissional em qualquer outro lugar.

A aquisição de infraestruturas não pode ser confundida com melhorias na qualidade de vida, mas sim com algumas facilidades que reduzem a quantidade de energia humana para o trabalho e intensificam a presença de entretenimento, informação e lazer.

As amostras familiares não proprietárias de terras são aquelas que provocam as maiores quantidades de deslocamentos e os maiores fluxos de deslocamentos. São deslocamentos sem destino e com as maiores intensidades nas rupturas e quebras nos laços de sociabilidade.

Foi identificada na amostra familiar que negociou a propriedade a presença de pequenos proprietários. A dimensão da propriedade pode aumentar ou reduzir o seu valor. Quando a propriedade é pequena, é comum o proprietário despender a força de trabalho em outras propriedades. O tamanho reduzido da propriedade, no processo de negociação, pode não oferecer valor suficiente para a aquisição de outra propriedade em condição melhor ou semelhante àquela negociada. Restou para a família, em eventual transação forçada, que é o caso, negociar a força de trabalho onde houver a oportunidade, ou seja, vender a propriedade significa perder a liberdade oferecida pela pequena propriedade.

As amostras familiares de pequenos proprietários e de não proprietários de terras que negociaram a propriedade, em dado momento após o deslocamento, ingressam em condições sociais e econômicas semelhantes. Para aquele que foi pequeno proprietário de terras agora lhe resta a força de trabalho e para aquele que não dispunha de propriedades permanece a negociação da força de trabalho.

Quando quem negocia a propriedade não é pequeno proprietário e não tem que despender atividades como trabalhador rural em propriedades vizinhas, o valor obtido com a negociação pode representar a possibilidade para adquirir outra propriedade. Esta particularidade, por que não, viabiliza o reinício das atividades de subsistência e pode proporcionar deslocamento reduzido, por exemplo, ao adquirir propriedade na sede do município que conhece e se reconhece, facilitando, desta maneira, a própria reorganização social, pessoal, familiar e econômica.

A amostra demonstra que, na cidade de Cerro Azul/ PR, foi iniciado processo de favelização pelas famílias deslocadas após a apropriação de propriedades. São famílias não proprietárias de terras e, à época, destituídas de indenização decorrente da negociação existente entre o proprietário e a CBA. Incluir as famílias não proprietárias de terras no processo indenizatório faz-se necessário, mesmo que a obra civil não tenha sido iniciada. 


\section{Referências}

AGÊNCIANACIONAL DE ENERGIA ELÉTRICA - ANEEL. Banco de Informação da Geração. Brasília, 2011. Disponível em: <http://www.aneel.gov.br/aplicacoes/capacidadebrasil/ capacidadebrasil.asp $>$. Acesso em: 22/05/2011.

BERMANN, Célio. Energia no Brasil: para quê? Para quem? Crise e alternativas para um país sustentável. São Paulo: Ed. Livraria da Física, FASE, 2001. 139 p.

BESTEL, J. R.; BESTEL, C. Depoimento. [nov. 2006]. Entrevista concedida a Alexandre Cosme José Jeronymo. Cerro Azul, PR, 2006.

BRASIL. Ministério de Meio Ambiente. Conselho Nacional de Meio Ambiente. Resolução n. 1, de 23 de janeiro de 1986. Dispõe sobre critérios básicos e diretrizes gerais para avaliação de impacto ambiental. Diário Oficial da República Federativa do Brasil, Poder Executivo, Brasília, DF, 17 de fev. 1986.

BRASIL. Decreto n. 23, 10 de setembro de 1996. Regulamenta a produção de energia elétrica por produtor independente, e dá outras providências. Diário Oficial da República Federativa do Brasil, Poder Executivo, Brasília, DF, 11 set. 1996, seção 1, p. 17.917.

Resolução n. 237, 19 de dezembro de 1997. Dispõe sobre os procedimentos e critérios utilizados no licenciamento ambiental [...]. Diário Oficial da República Federativa do Brasil, Poder Executivo, Brasília, DF, 22 dez. 1997.

Secretaria de Direitos Humanos da Presidência. Conselho de Defesa dos Direitos da Pessoa Humana - CDDPH. Comissão Especial de Atingidos por Barragens. Resoluções n. 26/06, n. 31/06, n. 01/07, n. 02/07, n. 31/07, Brasília, DF, 2010. p. 108.

BREIMA, J. Depoimento. [nov. 2006]. Entrevista concedida a Alexandre Cosme José Jeronymo. Cerro Azul, PR, 2006.

BRINI, A. Depoimento. [nov. 2006]. Entrevista concedida a Alexandre Cosme José Jeronymo. Dr. Ulysses, PR, 2006.

CASTRO, Eduardo Viveiros; ANDRADE, Lúcia. Hidrelétricas do Xingu: o Estado contra as sociedades indígenas In: SANTOS, Leinad Ayer; ANDRADE, Lúcia (Orgs.). As hidrelétricas do Xingu e os povos indigenas. Comissão Pró-Índio, 1988. p. 135-145.

COMISSÃO MUNDIAL DE BARRAGENS - CMB. Barragens e desenvolvimento: uma nova tomada de decisões. Trad. Carlos Alfonso Maferrari. Londres: Earthscan, 2000. 403 p.
COMPANHIA BRASILEIRA DEALUMÍNIO-CBA. Usinas: localidades. São Paulo, mar. 2009. Disponível em: $<$ http:// www.cia-brasileira-aluminio.com.br/pt/usinas.php $>$. Acesso em: 12/04/2011.

; COMPANHIA BRASILEIRA DE ALUMÍNIO CBA; CONSÓRCIO NACIONAL DE ENGENHEIROS CONSULTORES - CNEC. Impactos no meio socioeconômico. In: Estudo de Impacto Ambiental UHE Tijuco Alto. São Paulo: CBA \& CNEC, 2005a.

. Relatório de Impacto Ambiental da UHE Tijuco Alto. São Paulo: CBA \& CNEC, 2005 b.

COMPANHIA NACIONAL DE ENGENHEIROS CONSULTORES - CNEC. O Tijuco. Boletim Informativo do Empreendimento UHE Tijuco Alto, ano II, n. 4, dez. 2005. Disponível em: < http://www.usinatijucoalto.com.br/boletins.asp $>$.

O Tijuco. Boletim Informativo do Empreendimento UHE Tijuco Alto, ano III, n. 6, abr. 2007. Disponível em: < http://www.usinatijucoalto.com.br/boletins.asp $>$.

ELISEU. Depoimento. [nov. 2006]. Entrevista concedida a Alexandre Cosme José Jeronymo. Cerro Azul, PR, 2006.

GERMANI, Guiomar Inez. Os expropriados terra e água: o conflito de Itaipu. Salvador: Ed. Universidade Federal da Bahia e Ed. Universidade Luterana Brasileira, 2003. p. 266.

INSTITUTO SOCIOAMBIENTAL - ISA. Mapa do Vale do Ribeira. 2010. Disponível em: <http://www.socioambiental. org/inst/camp/tijuco/mapas/tijucositetijucosite1.GIF $>$. Acesso em: set. 2010.

Os impactos socioambientais que o EIA/Rima aponta. 2008. Disponível em: <http://www.socioambiental.org/inst/ camp/Ribeira/impactos $>$. Acesso em: mar. 2010.

JACOBI, Pedro. Governança institucional de problemas ambientais. Politica \& Sociedade, Florianópolis, n. 7, p. 119 137, out. 2005.

JEREMIAS, E. Depoimento. [nov. 2006]. Entrevista concedida a Alexandre Cosme José Jeronymo. Cerro Azul, PR, 2006.

INTERTECHNE ASSOCIADOS LTDA.; ENGENHARIA E GEOLOGIA - ENGEMIN; IPEC PLANEJAMENTO, ESTUDOS E CONSULTORIA LTDA. Aproveitamento Hidrelétrico Tijuco Alto - Rio Ribeira de Iguape: Estudo de Impacto Ambiental. São Paulo, 1991. 
LEROY, J. P. Prefácio. In: BERMANN, Célio. Energia no Brasil: para quê? Para quem? Crise e alternativas para um país sustentável. São Paulo: Ed. Livraria da Física, FASE, 2001. p. 7-9.

MACHADO, A.; SANTOS, E. M. Depoimento. [nov. 2006]. Entrevista concedida a Alexandre Cosme José Jeronymo. Cerro Azul, PR, 2006.

MANGUER, L. Depoimento. [nov. 2006]. Entrevista concedida a Alexandre Cosme José Jeronymo. Cerro Azul, PR, 2006.

MARTIN, J. M. A economia mundial da energia. São Paulo: Ed. UNESP, 1992. p. 135.

MARTINS, J. S. Migrações temporárias: problemas para quem? In: . Migrações temporárias: peregrinos da resistência. São Paulo: Serviço Pastoral dos Imigrantes, 1991. p. 23-60.

MOVIMENTO NACIONAL DOS ATINGIDOS POR BARRAGENS - MAB. Uma história de lutas, conquistas e desafios. Brasília: Caderno n. 7, 2004.

Dossiê: Ditadura contra as populações atingidas por barragens. 2006. Disponível em: <www.social.org.br/ denuncias.htm>. Acesso em: maio 2009.

PAULISTA, N. Depoimento. [nov. 2006]. Entrevista concedida a Alexandre Cosme José Jeronymo. Cerro Azul, PR, 2006.

PONTES, P. Depoimento. [nov. 2006]. Entrevista concedida a Alexandre Cosme José Jeronymo. Cerro Azul, PR, 2006.

PRADO, A. N. B. Depoimento. [nov. 2006]. Entrevista concedida a Alexandre Cosme José Jeronymo. Cerro Azul, PR, 2006.

RANCIÈRE, J. Entrevistas. Jornal do Brasil. Rio de Janeiro, 16 jun. 1996.

SÃO PAULO (Estado). Parecer 1.816, do relator especial, em substituição da Comissão de Constituição e Justiça, sobre o Projeto de Lei no 394/2007, vetado totalmente. Diário Oficial do Estado de São Paulo, São Paulo, 27 de julho de 2007.
. Assembleia Legislativa. Projeto de Lei n. 394/2007. Declara como patrimônio histórico, cultural e ambiental do Estado o rio Ribeira de Iguape. Sala de Sessões da Assembleia Legislativa do Estado de São Paulo, 3 de maio de 2007.

SEREIA, E. Depoimento. [nov. 2006]. Entrevista concedida a Alexandre Cosme José Jeronymo. Colombo, PR, 2006.

SIGAUD, Ligia. Implicações sociais da política do setor elétrico. In: SANTOS, Leinad Ayer; ANDRADE, Lúcia (Orgs). As hidrelétricas do Xingu e os povos indígenas. Comissão Pró-Índio, 1988. p. 103-110.

SILVA, J, C. Depoimento. [nov. 2006]. Entrevista concedida a Alexandre Cosme José Jeronymo. Cerro Azul, PR, 2006.

SOUZA, Alexandre do Nascimento; JACOBI, Pedro R. Licenciamento ambiental e ampliação da cidadania: o caso da Hidrelétrica Tijuco Alto. Organizações \& Sociedade, Salvador, v. 18, n. 57, p. 245-263, abr./jun. 2011.

SOUZA, O. Depoimento. [nov. 2006]. Entrevista concedida a Alexandre Cosme José Jeronymo. Cerro Azul, PR, 2006.

VAINER, C. População, meio ambiente conflito social na construção de hidrelétricas. In: MARTINE, George (Org.). População, meio ambiente e desenvolvimento: verdades e contradições. Campinas: Ed. Unicamp, 1996. p. 183-207.

; ARAÚJO, F. G. Grandes projetos hidrelétricos e desenvolvimento regional. Rio de Janeiro: Centro Ecumênico de Documentação e Informação - CEDI. 1992. p. 87.

WALDMANN, M. Ecologia e movimentos sociais: In: VIANNA, Aurélio (Org). Hidrelétricas, ecologia e progresso: contribuições para um debate. Rio de Janeiro: Centro Ecumênico de Documentação e Informação - CEDI, 1990. p. 33-54.

ZHOURI, A.; LASCHEFSKI, K.; PAIVA, A. Uma sociologia ambiental do licenciamento ambiental: o caso das hidrelétricas em Minas Gerais. In: ZHOURI, Andréa; PEREIRA, Doralice; LASCHEFSKI, Klemens (Orgs.). A insustentável leveza da politica ambiental: desenvolvimento e conflitos sociais. Belo Horizonte: Autêntica, 2005. p. 89-116.

Recebido em dezembro de 2011. Aceito em março de 2012. Publicado em junho de 2012. 